\title{
FROM JOKE TALES TO DEMOTIVATORS. A DIACHRONIC LOOK AT HUMOROUS DISCOURSE IN FOLKLORE
}

\section{LIISI LAINESTE}

Humor is a trans-genre phenomenon that functions above the established genre rules, challenging them through parody and other subversive practices. At the same time, genre rules have an influence on humorous discourse, but this often works in the negative: the rules are distorted in the process. Humor can thus be seen as counter-discourse, continuously and playfully deconstructing and reconstructing the text through adding new layers of meaning and context. Similarly to discarding genre rules, humor discards taboos and sabotages non-humorous discourse through performing the unexpected and the forbidden.

Keywords: humorous discourse, old folk jokes, punch-lined jokes, internet humor, folklore studies
Humor je nadžanrski pojav, ki deluje mimo ali proti uveljavljenim pravilom žanra, saj jih spodbija s parodijo in drugimi subverzivnimi praksami. Hkrati navidezna raba žanrskih pravil vpliva na šaljiv govor; to pogosto učinkuje kot zanikanje žanra, saj so pravila v samem procesu izkrivljena. Humor je tako mogoče razumeti kot proti-diskurz, kot stalno in igrivo dekonstrukcijo in rekonstrukcijo besedila $z$ dodajanjem novih plasti pomenu in kontekstu. In tako kot humor ovrže pravila pravila žanra, zavrže tudi tabuje in sabotira ne-humorni diskurz z rabo nepričakovanega in prepovedanega.

Ključne besede: duhovit diskurz, stare ljudske šale, internetni humor, folkloristika

Humorous expressions occur across a wide range of genres and forms; they are present in various cultures and many social circumstances. ${ }^{1}$ Psychologists, linguists, historians, sociologists, and researchers from many other disciplines have attempted to define humor, forcing it into different frameworks and models, but humor has for the most part evaded such attempts. The same terminological obscurity regarding humor is visible in folklore and anthropology. The anthropologist Mahadev Apte, for example, has conceded that humor exists in infinite varieties of form and modality, supporting the view that humor easily eludes strict definitions and generic specifications (1985). The questions that folklorists ask themselves while documenting and analyzing humor are quite nonspecific as well. They coincide with Victor Raskin's propositions about the basic and seemingly easy (yet largely unanswered) questions of humor research: what is funny, why it is funny, how it is funny, who it is funny to, and so on (see Raskin 2012). Through case studies and qualitative analysis, folklorists have looked most intensively at how humor functions and what it means for the people using it (Oring 2008: 185). These questions relate especially to the performance aspect of humor. They are not easy to answer because performance and the discourse it embodies are continuously changing, and the only constant factor is the playful and subversive character of humorous discourse.

1 This research was supported by the institutional research funding project IUT 22-5 and by the Center of Excellence in Estonian Studies (CEES). 
Some folklorists have conceptualized folklore as a cultural phenomenon that offers a counter-discourse to the official rules and conventions in society, challenging and perpetuating them at the same time. According to them, folklore in general displays functional similarities to Bakhtin's notion of carnival (Kumaraswamy 2006). On the other hand, this is also what humor does. Both folklore in general and jokelore in particular attack and restructure the order from below, through the voice of the common people, not those in power. Although the different levels of explanation and conceptualizations might become entangled here, it is illuminating to point out the commonalities of the two, both of which rebel against the official order, official discourse, and the rules set from above.

Most researchers agree that humor as it is now defined is common especially to humans, even though laughter is not unique to us: for example, it has been described among primates, which engage in rough-and-tumble play and tickling (for a brief overview, see Martin 2007: 2-5). The evolutionary importance of laughter makes it possible to assign important social and emotional functions to it. For the folklorist, however, humor rarely occurs in isolation or without the participation of a human agent; it is something that people create and share. People use humor for various purposes, some of which may at first seem contradictory: it is used to create social cohesion but can also function as an effective tool for excluding others, it signals resistance to rules but also exercises control over social behavior, it can express agreement and solidarity but also reinforce power hierarchies, and so on.

By entering the framework of humorous communication, the initiator of humor usually intends to make the audience laugh, and the listeners or readers in turn become involved in the interaction with the expectation to be amused. The intentions and reactions of the people taking part in the interaction are as important as the humorous text itself. In addition, humor cannot be defined solely on the basis of the genre it uses. There are genres that are usually considered humorous, the most evident of these being the old folk joke and the punch-lined joke. The ideas and tastes about "best humor" have changed in time along with the society, affecting the choice of genres considered to be the most typical expressions of folk humor (Kuipers 2008). Any of these primarily humorous genres—but also initially non-humorous forms of folklore expression-may cause amusement only when presented in a context that favors the humorous mode.

This article outline a folklore approach to the notion of humorous discourse, presenting examples from different time periods and genres. Without wanting to draw any generic boundaries, I analyze texts that are most easily agreed upon as humorous: old folk jokes, punch-lined jokes (more specifically, Soviet jokes or anekdoty), and internet humor in order to see how they function in various times. In conclusion, I hope to show that humorous discourse in folklore relies on both the content and context of folklore exchange, guiding the interpretation of the text, be it oral, written, or hybrid, as in the case of Internet communication, although the ambiguity of humor does not always yield a predictable reaction.

Humorous discourse turns the attention of the audience from the serious content to the entertainment value of the message. Many old folk jokes targeting neighbors and close 
kinship members carry a non-humorous message accentuating the differences between people and the difficulties in communication that derive from these. At the same time, the perception of these jokes was generally positive; for instance, Estonian old folk jokes were being collected and published as a legitimate part of folklore from the 1880s onward.

Humorous text, on the one hand, delivers a message, and on the other hand it undermines it. For instance, when a joke becomes popular on the internet and becomes an internet meme (see Shifman 2013) and reaches a huge audience, the reactions to it will still be influenced by the humorous discourse that the message was originally embedded in. Thus, the initiator of the joke (which may actually be a potentially hurtful message) might use the disclaimer "I was just joking" and shift the responsibility for the negative reactions solely onto the receiver. At the same time, pursuing the accusations on the grounds of tasteless humor simultaneously implies that the disapproving part of the audience does not possess a sense of humor, or, what is equally stigmatizing, their sense of humor is different (i.e., worse). "Unlaughter," a deliberate choice of not laughing at something that was communicated as funny, can in turn be laughable, and can become the perfect pretext in social inclusion and exclusion (see also Billig 2005).

This article is diachronically structured and presents examples of humorous discourse from three broad periods: the 1900s, the mid-twentieth century, and the beginning of the twenty-first century. These time periods are also differentiable on the basis of the humor used. The 1900s were the heyday for old folk jokes, in the mid-twentieth century jokes flourished, and the beginning of the twenty-first century saw the proliferation of internet humor in the form of visual humor (e.g., demotivators), multimedia texts (videos), and so on. The various humorous discourses are described and explicated, showing that humorous discourse is not dependent so much on the form or genre of the text (whether it is a joke or, say, a song, picture, or legend), but instead on the context it is embedded in. The material used for the study is taken from the Estonian folklore archive; nevertheless I believe it is possible to extend the conclusions to a more general level, not just concerning the Estonian material, thus leading to the idea of what humorous discourse in folklore is.

\section{FOLKLORE AND HUMOR}

Folklore is concerned with traditions that are known or practiced among groups of people. The classic definition of folklore posits that any folklore traditions (beliefs, legends, customs, and so on, and also humor) must be shared; they must also be anonymous (i.e., not attributed to a single author) and orally transmitted. This definition has undergone many adjustments since the nineteenth century. For example, the requirement of oral transmission has been dropped now. Similarly, the notion of authorship has frequently been challenged, and further conceptual confusion is added by the fact that present-day folklorists consider any human activity regardless of its anonymity or popularity to be worth their attention 
because they "study and discuss any expressive phenomena—urban or rural— that seem to act like other previously recognized folk traditions” (Toelken 1979). The unofficial, noninstitutional, and often forbidden expression and subject matter of humor has legitimized it as an appropriate subject for folklorists. It imparts essential truths about everyday life-the emotions, beliefs, stereotypes, and traditions of people - that are often unavailable or difficult to capture in other sources (Stokker 1997).

Within the Finnish school of folklore studies in the early twentieth century, the main purpose was to categorize the vast body of material according to text types and then trace the origins of folklore traditions through extensive historical and comparative research. The text was positioned in the center of research, and huge corpora of folk texts were collected and compared to describe the variants and determine the most authentic among them. Humorous texts or joke tales, forming a subsection in the Aarne-Thompson-Uther (ATU) index of folk texts, were distinguished from the rest of folklore by typical features (e.g., a clearly humorous content, a specific narrative form, a typical cast of characters, etc.; see Krikmann 2008). This approach was criticized by another influential group of folklorists in the second half of the twentieth century, who stressed the importance of performance, thus creating a new way of looking at folklore. For them, context mattered most in interpreting folk texts, and this view has persisted to the present day. The notion of discourse was introduced into the discipline later, stressing that the aim of studies in folklore discourse was to try to go beyond the description of the text and determine what is actually meant and being communicated, as opposed to only what is being said (Butler 1984: 38). Furthermore, they described the way folklorists had been writing about people's lore as a discourse that carried a particular aim (most importantly, they focused on how folklore studies displayed and constructed aspects of nation-building). Because the first of these uses interests me the most, I talk about discourse as an abstract concept within the toolbox of the folklorist rather than the other, metalevel approach to the entire discipline and its underlying ideologies.

Analyzing text as discourse could be done through "expanding" the text and including the explicit and implicit levels of the message. A piece of folklore is characterized thus not only by its form or content, but also by its intentions, use, and context(s). Consequently, the perception of the same ideas expressed within humorous and non-humorous discourse (e.g., ethnic jokes that usually reflect unflattering ideas entertained about neighboring nations) depends much on the context: who tells the joke, in what way, to whom, or why. What is funny to one person may not be funny to someone else; what is funny in one context may not be funny in another one. Moreover, one should distinguish between laughing at people acting according to stereotypical characteristics or at people that stereotype others. An audience that is narrow-minded enough to hold stereotypes in the first place makes a good target for jokes. This is often the case with internet humor, where humorous exaggeration of ethnic characteristics is stretched to the extreme, so that the audience is at the same time laughing at the target as well as at themselves (see Figure 2). 
Many genres of folklore make use of humor. Helga Kotthoff has stressed that humor calls for a flexible concept of genre not only because it is trans-genre by nature, but also because of the high degree of creativity, emergent construction, and artistry of humor (2007). The transgressions and swift changes in communicative processes can be accounted for only if genre rules are considered of lesser importance. In the same vein, contemporary folklorists admit that humor offers a frequent addition to almost any folklore genre, even those that are not usually considered humorous per se. Obituaries and tombstone engravings (Morreall 2013) can also be humorous-although this is not their main purpose. Humor is used there as an extra twist to the otherwise solemn message. In Romania, the famous Merry Cemetery (Cimitirul Vesel) is an example of the penetrating nature of folk humor; in South America, the Mexican Day of the Dead (Dia de Muertos) is yet another one (for a collection of studies on the unlikely alliance of death and humor, see Narvaez 2003). The close relationship between death and humor is also visible in various examples discussed below. On the whole, folklorists are often forced to address humor because it is embedded in all the genres they study, although not always because humor would be their main concern.

\section{TRANS-GENRE HUMOR: FROM OLD FOLK JOKES TO INTERNET HUMOR}

The old folk joke or the joke tale (German Schwank; also termed jest, see Kuipers 2008: 28 ) is formally much closer to its contemporaries, other old folklore narratives (e.g., animal tales, realistic tales or "novelles," and stories about a stupid devil, ogre, or giant; Krikmann 2003: 163). The rather rigid classification in ATU overlooks a number of other humorous formats that could well be seen as part of humorous discourse: narrative fantasies without a conflict or a solution built on various strategies such as lying, exaggeration, or the absurd; also, short forms of folklore that may be based on humor, such as quips, comparisons, metaphors, and other forms of figurative speech. On the other hand, the standard division of humorous folklore also lists a number of joke tales that are by now forgotten, although they used to belong to the treasury of the genre. Daniel Wickberg has suggested that old folk jokes quickly transformed as part of the many changes brought about by modernization of the society (1998). After the triumph of industrialization, which foregrounded urban culture instead of rural traditions, humorous texts became shorter, acquired a punch line (although some authors argue that this difference was not so clear-cut; e.g., Krikmann 2003, 2008), and could easily be transported from one context into another. These transformations are attributed to the need to create and consume (both listen and read) texts more quickly (see also Dorst 1990). Jokes proliferated in Eastern Bloc countries, which stood at the forefront of joke production (Krikmann 2009). "Jokes from behind the Iron Curtain" are sometimes considered the epitome of jokelore: they were truly the voice of the people, created anonymously, spreading quickly (Rebane 2012), and conveying important emotions through doing so. Many of these jokes have also fallen into the gray area 
of known and archived, but not actively used, jokelore. Another change occurred in the 1990 s, triggered by the dawn of the internet era. Suddenly jokes, finding their way into the new media, were mostly written, although in slangy language, or alternatively were not verbal at all. The new visual format increased the accessibility, dissemination, and popularity of humor. Humorous discourse in internet folklore is continuously becoming more prevalent and all-embracing in present times. Elliott Oring has stated that humor as expressed in jokes or other forms of folklore texts is now "recognized as the preeminent form of folklore expression in contemporary urban society" (2008: 183). Others have also noted the proliferation of humor on the Internet (Kirshenblatt-Gimblett 1996; Blank 2009, 2013) in innumerable formats, including humor formulated as lists, video/picture jokes, and so on (see Ellis 2001). Although real-life communication has been romanticized and sought in folklore studies - far before the internet, print was already regarded as a threat to folklore-researchers have had to go along with the changes in folklore. As the electronic vernacular has become the new print technology, the fears about the end of folklore did not come true. Instead, the internet is stimulating folklore exchange rather than extinguishing it. In the words of Trevor Blank, "[t]he Internet does not diminish the potency of folklore; it acts as a folkloric conduit" (2009: 7). Moreover, the abundance of material and ready availability of context (depending on the site, this may be the time of sending the joke, the user name, the user profile, etc.) makes this source a valuable mine of folklore data. Oring has concluded that "more may be known and knowable about the creators and purveyors of humor in cyberspace than about many joke tellers encountered face-to-face in everyday social interaction" (2003: 129-130). A large proportion of oral joke-telling has shifted to the new media, which easily crosses continental and linguistic barriers (Ellis 2001). This brings about new challenges for humor researchers, who need renewed methods for collecting and processing data, preferably together with the context, for a comprehensive study of humorous folklore discourse.

The abundance of jokes on the internet shows that these are in a close relationship with social reality: they are a tool for processing information, discussing issues, expressing the otherwise inexpressible or unpermitted, and so on. Some researchers suggest that, while orally transmitted pieces of folklore convey social fears and prejudices in a coded way, electronically transmitted narratives express these sentiments even more abrasively due to the anonymity of the senders (Blank 2009: 9). This again confirms the assumption that internet folklore is worthy of study—and lacks nothing, or maybe even adds something to studying only face-to-face communication. Equally important is the fact that humorous discourse is not limited to the traditional genres that were popular in their time (joke tales, jokes, or other epitomes of humorous genres); folk humor is still found in every kind of folklore exchange.

Having identified the most typical formats of humorous exchange- the old folk joke, the punch-lined joke, and internet humor-I want to stress that humorous discourse in folklore is not determined by the genre or the other way round. The same text can cause 
different reactions in different contexts, as will be seen, for example, in long-lived Soviet jokes (see below). All in all, my assertions here are that, first of all, humorous discourse in folklore is trans-genre (moreover, it is subversive towards genre rules), and, second, its functioning is highly dependent on the narrower social and wider cultural contexts.

\section{THE DISCOURSE OF OLD FOLK JOKES}

The best-known collector of Estonian old joke tales from the 1900s was the clergyman Matthias Johann Eisen. He published several volumes of folk jokes (1895-1910), each consisting of about two hundred unique texts. In his foreword to Eesti Rahvanali (The Estonian Folk Joke, 1909), Eisen claimed that jokes (even if they escaped the attention of collectors because they were considered too frivolous) needed to be documented and stored in archives for future generations. When translated jokes first started to appear in the Estonian daily Postimees in 1857, Eisen pointed to the immense treasury of local Estonian folk jokes that should be used instead. He did not, however, collect all jokes. His impartiality is evident in his statement that jokes must not be too obscene or blasphemous (Eisen 1909), which is why jokes about religion, clerics, and sexuality are underrepresented in his collections. There are, however, plenty of ethnic jokes and joke tales about marital relationships. The majority of old comic folk tales from Eisen's collection have become extinct by now because they were maladjusted for the new context of urbanization and modernization that started at the beginning of the twentieth century. Some joke tales were too long and complex to be remembered or retold; others were based on concepts or ideas that had lost their currency or comic potential. Sometimes the punch line was spelled out in all of its details, and yet other texts stopped before reaching the punch line altogether (see also Oring 1992: 81-82). Below is an example that resembles contemporary black/absurd humor, only that the solution does not seem particularly funny or incongruous enough. It is short and certainly easy to understand, but the absurdity of the humor does not outweigh the gravity of the situation:

"How's your deceased child?" a woman living on the coast asks another woman. - "Dead!" - "Did you cry when he died?" - "Sure I did! Ifyou wish, I could do so even right now." Eisen 1895/2002, no. 57: Kas surnud laps elab veel? (Is your deceased child still alive?) J. Ploompuu, Kuusalu Parish, northern Estonia.

The content as well as the context of these joke tales does not support their existence in other time periods, and it shows how closely these two aspects are linked to interpreting something as funny or not funny; as belonging to a humorous discourse or not. Continuing from here, there are also old folk texts that were not classified under humor (e.g., legends, treasure stories, and folk songs such as lullabies or men's songs), but they still relied largely on humorous details or were fully based on a humorous set of motifs. It is not always easy to 
read the actual use of the text from an archived written text only. The performance aspect of old archived folk texts is often reduced to a few basic details (usually the name of the performer and the place it was recorded). The same story read as a text or heard from the tape can direct the researcher towards different ideas about the message, mainly because of the tonality of the performance. Bill Ellis, researching contemporary legends, has noted that hearing the laughter in the recordings (left out from the transcriptions) offers a new direction for the interpretation of the researcher (Ellis 1987: 54-57). The presence of the humorous discourse is not self-evident by looking at the texts only; one has to know the context as well to decide on that. The following treasure legend, complete with the added comments missing from the text in the archive entry, obtains an entirely new layer that can be identified as a humorous discourse, downplaying genre rules and adding ambiguity to the intended message (cited in Kalda 2010: 876):

Grandmother used to tell this. ... The old man put the gold in there, in the old times there were these things in the byre dwellings, these hearths, hearths with ashes. The big stove and then there - something in front of it where the ashes were scraped. [snickering] The old man put his gold there, damn it, before he died. He said: "Whose hand shall put, shall also take." The old man died [continues with a laughing voice] and the women dragged the old man there, digging in the ashes with his hand. I don't know whether they got anything or not. [change of tone] Grandmother told that.

RKM, Mgn II 3073 (12) < Simuna khk, Käru - O. Kõiva, A. Tael, M. Jallai < E.K., 74 a (1978).

As pointed out by Mare Kalda, all of the recordings of versions of this story from 1960 to 1982 include laughter, which accompanies the description of trying to exhume the treasure with the hand of the dead person, the former owner of the gold. This indicates that the story itself triggered the laughter. In other cases, the accompanying emotion is not amusement but is better characterized as embarrassment, an emotional struggle of being torn between believing and not believing in old legends. In this case, laughter does not signal the presence of a humorous modality. For example, a number of ghost stories about the building of the Estonian Literary Museum are told by the researchers that work in the building, some of whom have had supernatural encounters with the most frequent of the ghosts, the Lilac Lady. Eda Kalmre (2001: 84-85) recorded a story-telling event in which the belief in the ghost of the building was deemed both ridiculous and believable at the same time:

A: This was just one of these jokes. Connected to the new building being under construction again and again. And then there was this legend that each time the new extension was built someone died, and the victims were all men. But then this Lilac Lady adopted modern ways, no gender discrimination, so to speak, and took a woman [both of them are laughing]. The newest house went with a woman. 
$B$ : With that cinnamon braided bread [a common dessert at celebrations]?

A: Well, yes, this was a moment of emotional awareness. I think she went with that cinnamon bread? [Laughing]

B: Well, she had one, the cinnamon bread was found there on the shore, and she was in the water. That's what they said: [drowned in a] half meter water, right at the shore. And she was lying there, the cinnamon bread next to her. That was spooky. Otherwise the cellars never frightened me, not the least, but then it was spooky sometimes.

A: Yes, it was.

B: And especially once when T. came from the cellar to the researcher's room, and we were all sitting there and she asked, what are you doing here? Just sitting, I said. Oh, but I just saw you in the cellar! [One of the speakers laughs] You went along the hallway, skirt flapping behind you. She didn't even close the cellar door, thought that . . and she came upstairs, didn't shut the door, believed I was down there. And I was so frightened that I was afraid to go down to the cellar alone after that. I told her, let's go together, but I think she was afraid, too [Both of them are laughing].

Comic effect may also be added through the choice of words and images that are activated when the story is told, thus functioning as a rhetorical technique (Oring 2008: 130). Among many stories about the dead waking up before or during the funeral, some of which end with a remark that gets quite close to becoming a punch line (e.g., the dead man asks if he can have a bowl of the cold pea soup from the previous day), there are those that display such a technique:

I was in the hospital and a man there told me this story. There was a funeral and they had started to lower the body into the grave. The priest was at the grave, giving a sermon, when suddenly the dead man started to move. Everybody ran away, and the priest in his long coat, after everybody else, threw the Bible on the ground [and ran]. The dead man didn't understand what the rush was about and began to run after them. So the old folks don't say in vain that you have to wait three days before the burial, or else the dead will come to life.

RKM, II 403, 246 (6) < Juuru - E. Kalmre < K.K., 85 a (1987).

So, in addition to examples of typically humorous discourse (genre-wise, belonging to the "joke tale" category in the ATU index of folk tales), I have described a number of exceptions: joke tales that are no longer humorous, and stories that are typically not seen as humor but may function as such when performed in a humorous mode or using comic vocabulary, figures of speech, or images. Thus, there are viable examples of humorous discourse from the earliest records of Estonian folklore that would not usually be classified under humor, although they might well have functioned as such-and in some cases still do. 


\section{THE DISCOURSE OF PUNCH-LINED JOKES}

In Soviet times, jokes (or anekdoty, as they are sometimes referred to in academic literature to stress their status in the particular period and region; see, e.g., Graham \& Mesropova 2008) were a very popular past-time, which has even led some researchers to say that after the collapse of the Soviet Union jokes also disappeared from oral circulation (Draitser 1998). The reality was not so dramatic, but the importance that jokes carried for a Soviet citizen cannot be denied. The Soviet jokes had a general political overtone and, mocking all aspects of absurd everyday life, they turned almost every comment about work, sex, or ethnic relations simultaneously into a political one. The omnipresent skepticism and nihilism of the Soviet jokes made a point of discrediting the regime by using every aspect of Soviet life as an inspiration (see also Graham 2003: 98). The absurdity is clearly visible in accounts about Soviet joke-telling. In a rather small case study by Rebane (2012), informants that were young in Soviet times and had close contact with their contemporary jokelore were interviewed to reveal the mechanisms of joke distribution. When recounting their experience, they mentioned that jokes were often told in small groups; not only among close friends or relatives, but also among coworkers or people traveling together. Invariably, the jokes provided a comment on some acute absurdity. One of the informants mentioned a joke exchange that followed a complaint about a particularly nonsensical command from a job supervisor. She turned to a coworker for consolation, and the latter answered with the following joke:

\section{The kolkhoz chairman informs Leida that a reporter will come to interview her the day after. "What's that?" asks Leida. "I don't know either, but put on a clean slip, just in case!"}

(cited in Krikmann 2009: 53).

The point of the joke was to comment on orders that are given from above, and the joke about the milkmaid Leida Peips ${ }^{2}$ offered her, as she said even decades later, comfort and insight concerning the quality of the orders that came from higher officials (Rebane 2012: 113).

Many of the jokes known then are not possible now or would not function as they originally did. The following joke, not known on the internet, is another typical specimen of Soviet jokelore, referring to the scarcity of living space (the scarcity was extendable to other areas of life too):

2 The milkmaid Leida Peips joke cycle was popular in the 1970s and 80 s. She was a well-known figure because of her status as a labor hero, thus belonging to a customary system of symbols and icons in Soviet times used to promote the advantages of Soviet power and the working enthusiasm of the Soviet people. She was subsequently elected to the Supreme Soviet, shook hands with Leonid Brezhnev, and became a laughing stock in Estonian jokes. 
How does Juku conjugate the Estonian verb 'build' in Estonian? - "I build, you build, helshe builds, we build ... they move in."

Viikberg 1997, p. 18 (1975)

Although it is possible to decipher this example quite successfully, there are yet others that need a lot of more knowledge of the context, as well as also a suitable state of mind to appreciate; for example, the pun in the following line, originating from a popular Soviet song written by Isaak Dunaevski and translated into Estonian (cited in Krikmann 2009: 58-59):

\section{"Meil lalulud aitavad elada, vôita" pro "Meil laulud aitavad elada vôita" \\ "Songs help us to live and win" vs. "Songs help us to live without butter"}

The homonym (vöita) carries a double meaning: võita is the $d a$-infinitive of the verb vôitma 'to win' and also the abessive case (corresponding to the preposition 'without') of the noun vôi 'butter', and this knowledge is necessary to see the double meaning and appreciate the pun.

At the same time, some jokes retain their comic effect even when the topic (or, as in the following example, the main character) has lost its currency in the jokelore. In this case, there is some other reason to distribute the old Soviet joke besides its original political undertone: absurdity, the sexual topic exploited in the joke, and so on. It is debatable if the formerly political joke will now be perceived as apolitical (if the wording remains largely the same), but at least politics is no longer the focus, even if it is categorized on joke web sites under the label "political." Other aspects of the joke prevail, as in the following joke, where in the contemporary presentation the political power relations give way to a much stronger sexual script:

A Russian and a Chukchi are fighting on the street. The policeman approaches them: "What is going on here?" "We are arguing about who the master of Chukotka [the Chukchi Peninsula] is," the troublemakers answer. "You will continue the argument in jail," says the police officer. The next morning the policeman asks them: "Did you solve your issue?" "Yes," answers the Chukchi, "The Russian is the master, and I'm the mistress." (Delfi, Dr Huibolit, May 28th, 2004, www.delfi.ee)

These jokes, like the one about the Chukchi and the Russian, are not strictly regimeor society-specific. Some political jokes do travel from society to society because folklore constantly changes, merges, and diffuses. The popularity of the anekdoty was and still is dependent on the attractiveness and ambivalence of the text itself, the context for the humorous text, and also the medium where the joke spreads (whether orally or in a written form on the internet, living its "second life"); at times, even the season (see Aikat 1998; Laineste 2003). Although they have survived through the years, the old Soviet jokes have 
turned almost apolitical, carrying a nostalgic or mythological meaning (which has become trendy in the past decade; see writings on nostalgia; e.g., Boym 2001). The old Soviet jokes told today need more explaining and cannot be understood without some additional clues. In many cases, joke-senders on the internet joke sites add introductory sentences like "That happened way back in Soviet times" or "Remember this old joke."

\section{THE DISCOURSE OF INTERNET HUMOR: TOPICAL JOKES}

The classical punch-lined joke, being on the decline, has been partly replaced by various humorous genres made available on the Internet. Humor seems to be an essential feature of the whole internet, not only sites specializing in jokes, and it guarantees audience appeal (Kirchenblatt-Gimblett 1996; Baym 1995). It may provide rules about life, including about the life people lead on the internet (Figure 1):

Internet humor has brought about a number of generic adjustments, some of which were also visible in its predecessor, Xerox- or faxlore (Dundes \& Pagter 1978; see also Figure 2). Humor on the internet rarely takes the form of a traditional punch-lined joke, and relies increasingly on the visual. Typical for internet humor, previous texts (including other users' comments about the humor) are often cited to create parody. Intertextuality is a common feature of this medium. Citations of known humorous texts (also parts or punch lines of jokes; see also Shmeleva \& Shmelev 2009: 225) have become popular instead of the full texts of jokes because, even though the joke form has considerably shortened since the days when the old joke tale was the prototype of folk humor, they are still too long for the purposes of online communication. Faxlore as the predecessor of internet jokelore was disseminated

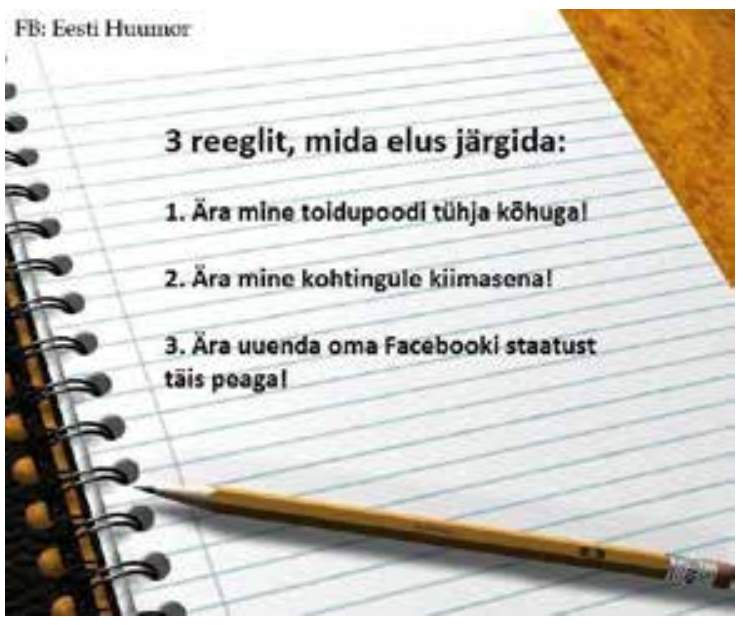

Figure 1. Three rules to live by: 1 . Don't shop when you're hungry! 2. Don't date when you're horny! 3. Don't update your Facebook status when you're drunk! via modern office technology, fax, and Xerox machines - and, being in itself a mild misappropriation of these tools, it was often inspired by subversive sentiments against the workplace and its values. Thus, it worked best in the office environment, probably printed out and hung on the wall, usually near the respective office machines where most people would see them during their workday. The target might have been the boss, colleagues, or the fact that the former did not appreciate the efforts of the latter (Figure 1), but the essential feature 


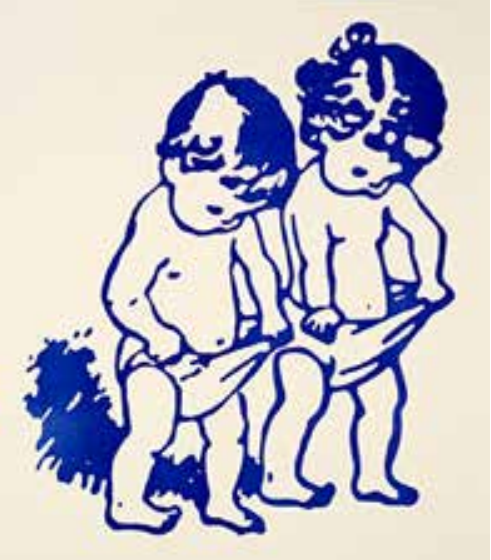

Oh, so that explains the

difference in our salaries!

Figure 2. Faxlore (http://sinavil.blogspot.com/2009/09/oh-so-that-explainsdifference-in-our.html) was its novel format, which was not confined to the requirements of an orally transmitted text.

Because faxlore seems outdated by now, the internet offers numerous opportunities to fill the need for similar trans-genre multimedia texts distributed with the aim of making people laugh. The closest to the previous example is the genre of demotivators. These are posters or pictures, usually set on a black background with a short caption and a title explaining or providing a mock-psychological or pedagogical addition to the picture. The image does not usually stand independently. It is the titles and captions that are the focus of attention and that perform as the lever that makes an ironic twist to a rather ordinary (sometimes provocative) picture. Many demotivators touch upon general and easily translatable issues such as relationships (Brzozowska 2011; see also Figure 3) or ethnic stereotypes (Boxman 2012), which travel across country and language borders.

At the same time, the format is well adjusted for topical commentary as well because it allows for quick creation and dissemination of new texts. In a slightly unorthodox format, Figure 4 blends two topics relevant in 2012: the foretold end of the world on December 21st, 2012, and the slogan from a recent political election campaign. Although the format may be taken as a typically humorous one, Figure 4 carries a much narrower potential for humor across time and space: it may not be funny for those unaware of the apocalyptic premonitions, or for those unfamiliar with the political figure of Edgar Savisaar, the mayor of Tallinn. Thus, although the format indicates one is dealing with an instance of humorous discourse, it may not be recognized as humorous because of the lack of contextual knowledge on the part of the audience.

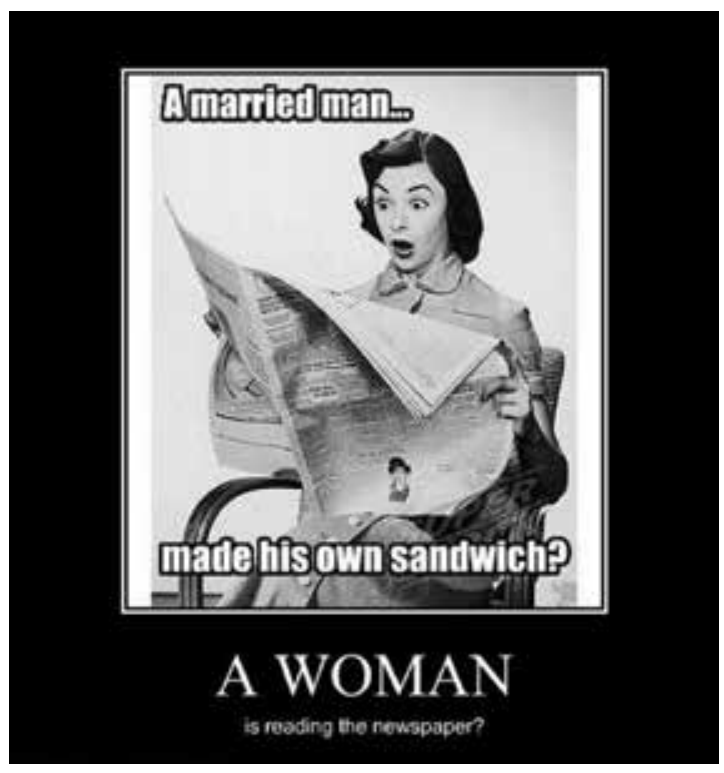

Figure 3. Demotivator concerning gender stereotypes (http://memebase.cheezburger.com/verydemotivational/tag/sandwich/page/2) 


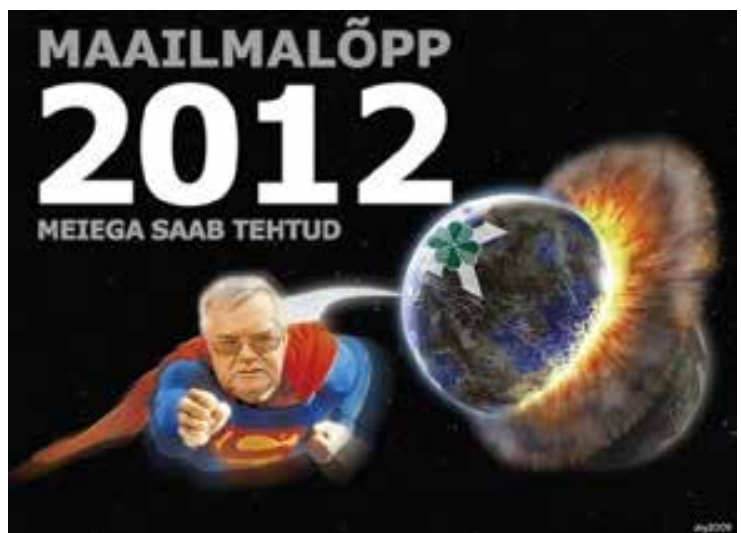

Figure 4. Demotivator blending local and global topical issues. 'End of the world 2012: With us, consider it done.' (http://www.hullumaja.com/?pg=main\&i=251427)

Following the same line of reasoning, there are examples of texts that are perceived as funny only by a small part of the audience, and the rest may be indifferent to the text or object to it, considering it to be insulting or blasphemous. These are again quite often in a visual format (Baran 2012: 172). The controversial images spark discussions about tastes: what is acceptable and unacceptable in humor, and how to define humor in the first place. The lay definitions of humor presented in the course of these discussions are quite revealing in themselves because they show that there is no agreement about what humor is: is it a genre-based phenomenon, or something defined by the intention of the joke-teller, or, instead, by the reaction of the audience (Laineste 2011)? What folklorists choose to describe as a humorous discourse, be it on the internet, from oral circulation, or from the archives, is a configuration of these elements. The way a text considered humorous at any of these levels works (or fails to work) is at the center of their academic interest.

\section{DISCUSSION: HUMOROUS AND NON-HUMOROUS DISCOURSE IN FOLKLORE}

The notion of discourse is rather ill-defined within the discipline of folklore studies, and it seems to coincide and partly overlap with other terminology such as framing, keying, performance, rhetoric, or context. All of these have to do with the text in use, not in isolation. Humor is as much in the intention of the teller and the perception of the receiver as it is in the text. The circumstances must support the joke both at an immediate contextual level and at a broader cultural level (or, as Dan Ben-Amos puts it, through the contexts of situation and culture; 1993: 215-216). First of all, the audience must understand the language, they have to be prepared to hear the joke, they have to accept the joke-teller as a member of their group or at least not a hostile agent, and so on. Second, the cultural codes and symbols used in the joke must be known to the audience, and the joke must meet their cultural expectations, social conventions, and beliefs. Although some topics are too serious to be joked about, and there might be quite a general consensus (at least for a while) that "jokes are a rebellion against the official discourse about humor: that humor is inappropriate in times of disaster" (Kuipers 2011: 43), humor constantly tries the limits of 
intercultural understanding, sometimes causing conflicts and confusion (as was the case with the Mohammad cartoons; for a discussion, see Lewis 2008).

Humor is a trans-genre phenomenon seen in some form and degree in almost all folklore genres. The use of known genres in a new context may already be enough to create humor. For example, advertisements sometimes make use of fairy tales or proverbs because these, like ads themselves, are used to educate, persuade, and entertain, with the prospect of a happy ending. However, some advertisements apply fairy-tale motifs in a subversive and humorous way (for examples, see Järv 2013). A Christmas-time ad that advertises meat factory products by presenting a fairy tale of a pig couple and their happily ending love story (ibid: 107-108) is deliberately playing with the structure of a genre (a fairy tale) and an unavoidable unhappy end for the pigs (ending up as Christmas dinner), thus simultaneously referring to a structure and a subversion of that structure within one text through the means of humor. Humor may penetrate different genres, and, being ambiguous, does so with unforeseeable results; the reaction may be laughter, but it can also be disgust. One may say that when a genre (as well as a discourse in general) gives a set of rules-a more or less fixed pattern derived from the intention and aims of the communicative event enacted through the content, structure, wording, and so on of the utterance-then the recognition of a humorous discourse provides the expectation that violations of these norms and patterns will occur. Thus, in a way, humor is an anti-discourse, subversive towards fixed rules of genre, constantly restructuring the outcome of every individual performance of folklore texts.

\section{CONCLUSION}

Rod Martin, while describing humor through its social, cognitive-perceptual, emotional, and vocal-behavioral contexts or components, places play at the center of the phenomenon (2007: 6). Alongside other prominent humor scholars (Davies 1990, 2002, 2011; Oring 2003), he stresses that people adopt a non-serious attitude primarily because they are drawn to the play element itself, and not because they want to achieve some particular ends while doing so. Seeing humor as a basically mirthful activity takes the emphasis away from trying to list all the possible functions of humor-of which there are many, and that are often contradictory, as noted before-to concentrating on what is actually being said, how it is said, and what effect it has on the people involved.

Folklorists are interested in humorous discourse from the point of view of its actualization in communication because they often witness folklore exchanges in contexts where humor is lost or where it is unexpectedly created regardless of the actual message. Thus, one can say that humorous discourse in folklore is a way of talking about things that is arbitrary to the genre of the text. Humor is mainly performed with an aim to entertain, creating meaning from past and current texts in a playful and taboo-free manner. 
No piece of humorous text works in isolation. In the words of Arvo Krikmann, "no joke, as an individual text (conveyed orally or presented on paper or on the Internet) exists in a vacuum, but is in various ways-associatively, genetically, or otherwise-connected with the other texts preserved in the collective memory and shared among the members of joke-making communities. They also interact with events and situations in the outside world" (2009: 61). Humorous discourse habitually makes allusions to other cultural texts through citations or parody. It is shaped by its immediate and social context, cultural implications, the channel of its distribution, and so on. Analyzing humorous discourse must take all of these aspects into account, simultaneously accepting that humorous discourse is not genre-specific, nor a stable or fixed phenomenon. It may permeate any kind of folklore exchange, and whether the participants are willing and capable of accepting the humor depends on the particular situation.

\section{REFERENCES}

Aikat, Deb D. 1998. News on the Web: Usage Trends of an On-Line Newspaper. Convergence: The Journal of Research into New Media Technologies 4(4): 94-111.

Apte, Mahadev. 1985. Humor and Laughter: An Anthropological Approach. Ithaca, NY: Cornell University Press.

Baran, Anneli. 2012. Visual Humor on the Internet. In: Liisi Laineste, Dorota Brzozowska, \& Władysław Chłopicki (eds.), Estonia and Poland: Creativity and Tradition in Cultural Communication, vol. 1, pp. 171-186. Tartu: ELM Scholarly Press.

Baym, Nancy K. 1995. The Performance of Humor in Computer-Mediated Communication. Journal of Computer-Mediated Communication 1 (2), available at http://kuscholarworks.ku.edu/dspace/ bitstream/1808/8710/3/Baym_1995_Humor-Computer-Mediated.pdf.

Ben-Amos, Dan. 1993. "Context” in Context, Western Folklore 52: 209-226.

Billig, Michael. 2005. Laughter and Ridicule: Towards a Social Critique of Humor. London: Sage

Blank, Trevor. 2009. Folklore and the Internet. Vernacular Expression in a Digital World. Logan: Utah University Press.

Blank, Trevor. 2013. The Last Laugh: Folk Humor, Celebrity Culture, and Mass-Mediated Disasters in the Digital Age (series: Folklore Studies in a Multicultural World). Madison: University of Wisconsin Press.

Boxman, Lillian. 2012. Ethnic Humor in the Digital Age: A Re-Evaluation. Presentation at the International Society for Humor Studies Conference, Krakow, Poland, June 25th-29th.

Boym, Svetlana. 2001. The Future of Nostalgia. New York: Basic Books.

Brzozowska, Dorota. 2011. Gender Stereotypes in Polish Family Jokes. Presentation at the International Society for Humor Studies Conference, Boston, July 5th-9th.

Butler, Gary. 1984. Folklore and the Analysis of Folk Discourse: Cultural Connotation and Oral Tradition in Communicative Events. Toronto Working Papers in Linguistics 5: 32-50.

Davies, Christie. 1990. Ethnic Jokes around the World. Bloomington: Indiana University Press.

Davies, Christie. 2002. Mirth of Nations. New Brunswick, NJ: Transaction Publishers. 
Davies, Christie. 2011. Jokes and Targets. Bloomington: Indiana University Press.

Dorst, John. 1990. Tags and Burners, Cycles and Networks: Folklore in the Teletronic Age. Journal of Folklore Research 27(3): 179-190.

Draitser, Emil. 1998. Folk Humor of Post-Soviet Russia: A Survey. Slavic and East European Folklore Association Journal 3(1): 5-13.

Dundes, Alan, \& Pagter, Carl R. 1978. Work Hard and You Shall Be Rewarded: Urban Folklore from the Paperwork Engine. Bloomington: Indiana University Press.

Eisen, Matthias Johann. 1909/2003. Eesti rahvanali. Available at http://www.folklore.ee/rl/pubte/ee/ vanad/eisen/ernali/sisu.html.

Ellis, Bill. 1987. Why Are Verbatim Texts of Legends Necessary? In Gillian Bennet, Paul Smith, \& J. D. A. Widdowson (eds.), Perspectives on Contemporary Legend 2, pp. 31-60. Sheffield: Sheffield Academic Press.

Ellis, Bill. 2001. A Model for Collecting and Interpreting World Trade Center Disaster Jokes. New Directions in Folklore. Available at http://www.astro.temple.edu/ camille/journal.html.

Graham, Seth. 2003. A Cultural Analysis of the Russo-Soviet Anekdot. Doctoral dissertation, University of Pittsburg. Available at http://d-scholarship.pitt.edu/9560/1/grahamsethb_etd2003.pdf.

Graham, Seth, \& Olga Mesropova. 2008. Reinventing Humor and Satire in Post-Soviet Russia. Columbus, $\mathrm{OH}$ : Slavica.

Järv, Risto. 2013. A Hen Who Doesn't Lay Golden Eggs? Fairy Tale Advertisements and Their Strategies. In Liisi Laineste, Dorota Brzozowska, \& Władysław Chłopicki (eds.), Estonia and Poland: Creativity and Tradition in Cultural Communication, vol. 2, pp. 99-120. Tartu: ELM Scholarly Press.

Kalda, Mare. 2010. Eduelamuse ootel. Naer aardejuttudes ja jutustamise saateks. Keel ja Kirjandus 12: 873-889.

Kalmre, Eda. 2001. The Lilac Lady. A Collective Belief-Legend as a Homogenous Entity. In: Jürgen Beyer \& Reet Hiiemäe (eds.), Folklore als Tatsachenbericht, pp. 85-106. Tartu: Sektion für Folkloristik des Estnischen Literaturmuseums.

Kirshenblatt-Gimblett, Barbara. 1996. The Electronic Vernacular. In: George E. Marcus (ed.), Connected: Engagements with Media, pp. 21-66. Chicago: University of Chicago Press.

Kotthoff, Helga. 2007. Oral Genres of Humor: On the Dialectic of Genre Knowledge and Creative Authoring. Pragmatics 17(2): 263-296.

Krikmann, Arvo. 2003. Puändita naljandite struktuurist. Keel ja Kirjandus 3: 161-177.

Krikmann, Arvo. 2008. "ATU Jokes": Old and Abandoned. Presentation at the International Society for Humor Studies Conference, Alcalá de Henares, Spain, July 7th-11th. Available at http://www. folklore.ee/ kriku/HUUMOR/KRIKMANN_ATU_ready.pdf.

Krikmann, Arvo. 2009. Jokes in Soviet Estonia. Folklore. Electronic Journal of Folklore 43: 43-66.

Kuipers, Giselinde. 2008. Good Humor, Bad Taste. A Sociology of the Joke. Berlin: Mouton de Gruyter.

Kuipers, Giselinde. 2011. Where Was King Kong When We Needed Him? Public Discourse, Digital Disaster Jokes, and the Functions of Laughter after 9/11. In: Ted Gournelos \& Viveca Greene (eds.), A Decade of Dark Humor: How Comedy, Irony and Satire Shaped Post-9/11 America, pp. 20-46. Jackson: University Press of Mississippi. (Updated reprint of a 2005 article from Journal of American Culture).

Kumaraswamy, Muthu. 2006. Folklore as Discourse. Chennai: National Folklore Support Centre.

Laineste, Liisi. 2003. Researching Humor on the Internet. Folklore 25: 93-97. 
Laineste, Liisi. 2011. Politics of Taste in a Post-Socialist State: A Case Study. In: Villy Tsakona \& Diana Popa (eds.), Studies in Political Humor: In between Political Critique and Public Entertainment, pp. 217-241. Amsterdam: John Benjamins.

Lewis, Paul (ed.) 2008. The Muhammad Cartoons and Humor Research: A Collection of Essays. Humor: International Journal of Humor Research 21(1): 1-46.

Martin, Rod. 2007. The Psychology of Humor. An Integrative Approach. Burlington, MA: Elsevier Academic Press.

Morreall, John. 2013. End of the World as a Humorous Subject across Cultures. Presentation at the International Society for Humor Studies Conference, Williamsburg, VA, July 2nd-6th.

Narvaez, Peter. 2003. Of Corpse: Death and Humor in Folklore and Popular Culture. Logan: Utah State University Press.

Oring, Elliott. 1992. Jokes and their Relations. Lexington: University Press of Kentucky.

Oring, Elliott. 2003. Engaging Humor. Urbana: University of Illinois Press.

Oring, Elliott. 2008. Humor in Anthropology and Folklore. In: Victor Raskin (ed.), The Primer of Humor Research, pp. 183-210. Berlin: Mouton de Gruyter.

Raskin, Victor. 2012. A Theory's Purview: What Is Reasonable to Expect from a Theory of Humor. Presentation at the International Society for Humor Studies Conference, Krakow, Poland, June 25th-29th.

Rebane, Martin. 2012. Some Aspects of Telling Political Jokes in Soviet Estonia. In: Liisi Laineste, Dorota Brzozowska, \& Władysław Chłopicki (eds.), Estonia and Poland: Creativity and Tradition in Cultural Communication, vol. 1, pp. 111-116. Tartu: ELM Scholarly Press.

Shifman, Limor. 2013. Memes in Digital Culture. Cambridge, MA: MIT Press

Shmeleva, Elena, \& Alexey Shmelev. 2009. Contemporary Russian Jokes: A New Cast of Characters. In: Arvo Krikmann \& Liisi Laineste (eds), Permitted Laughter: Socialist, Post-Socialist and Never-Socialist Humor, pp. 225-236. Tartu: ELM Scholarly Press.

Stokker, Kathleen. 1997. Folklore Fights the Nazis. Humor in Occupied Norway, 1940-1945. Madison: University of Wisconsin Press.

Toelken, Barre. 1979. The Dynamics of Folklore. Boston: Houghton Mifflin.

Viikberg, Jüri. 1997. Naeruga eilsest: Eesti anekdoot 1960-1990. Tallinn: Eesti Keele Sihtasutus.

Wickberg, Daniel. 1998. The Senses of Humor: Self and Laughter in Modern America. Ithaca: Cornell University Press. 


\section{OD ŠALJIVIH PRIPOVEDI DO DEMOTIVATORJEV. DIAHRONI POGLED NA HUMOREN DISKURZ V FOLKLORI}

Humor je nadžanrski pojav, ki deluje mimo ali proti uveljavljenim pravilom žanra, saj jih spodbija s parodijo in drugimi subverzivnimi praksami. Hkrati navidezna raba žanrskih pravil vpliva na šaljiv govor; to pogosto učinkuje kot zanikanje žanra, saj so pravila v samem procesu izkrivljena.

Humor je tako mogoče razumeti kot proti-diskurz, kot stalno in igrivo dekonstrukcijo in rekonstrukcijo besedila $z$ dodajanjem novih plasti pomenu in kontekstu. In tako kot humor ovrže pravila pravila žanra, zavrže tudi tabuje in sabotira ne-humorni diskurz z rabo nepričakovanega in prepovedanega.

Avtorica ugotavlja, da je funkcija humornega diskurza v folklori situacijsk in kulturna bogatitev besedila in njegovega konteksta; pri analizi pa je treba upoštevati zgodovino humornega izročila in njegov pomen $v$ različnih časovnih obdobjih. Te raziskovalne nianse ponazori na primerih humornega diskurza $v$ zgodnjem 20. stoletju, $v$ casu Sovjetske zveze in sodobnem času, $v$ katerem prevladuje internetni humor. $Z$ analizo avtorica razkriva, da je humorni diskurz širši kot samo besedilo. Da bi ga bolje razumeli in cenili, pa je pomembno in potrebno razmisliti o neposrednih socialnih in sirših kulturnih kontekstih.

Dr. Liisi Laineste, Department of Folkloristics, Estonian Literary Museum, 50003 Tartu, Estonia, liisi@folklore.ee 